\title{
Cultural Crossovers in the Sicily of Vincenzo Consolo
}

\author{
Cinzia Gallo \\ Università di Catania, Syracuse, Italy
}

\begin{abstract}
In his Il pensiero meridiano, Franco Cassano identifies the Mediterranean as the meeting point of a number of cultures which can interact with each other without losing their own identities and, in southern Europe, Italy, and Sicily in particular as a major linking bridge. These ideas are fundamental to the fictional works and essays of Vincenzo Consolo. He dedicates the same energy to both these areas, and draws a vital distinction between "writing" and "narrating", history and memory, and the contribution of Arabs and Africans to the formation of the Sicilian and Italian identity. We may consider, for example, Lo spasimo di Palermo, Di qua dal faro, and Retablo, in which, just as in Le pietre di Pantalica, his debt to Greek culture is also clear. For this reason, Consolo is not only able to define Sicily as a land "d'antiche migrazioni, d'incroci fruttuosi di culture" (Natali sepolti, in La mia isola è Las Vegas), but also, thinking of the Africans who surround him, in Milan, with "con un'ondata di mediterraneità, di meridionalità", is aware of "una sensazione di distensione, di riconciliazione" (Porta Venezia). Otherness therefore is not a threat, but an enrichment. Consolo himself has admitted that his modes of expression reveal the fertile cultural crossovers typical of Sicily. One example of this is the linguistic blending that can be found in
\end{abstract} Lunaria.

Keywords: Sicily, crossovers, culture, space, literature

\section{Introduction}

Consolo believes that relationships between space and literature are deep. He in fact writes following words in Memorie:

Mi sono ispirato, narrando, a questo mio paese, mi sono allontanato da lui per narrare altre storie, di altri paesi, di altre forme. Però sempre, in quel poco che ho scritto, ho fatalmente portato con me i segni incancellabili di questo luogo. [...] Credo [...] di non aver mai smesso di essere uomo di quest'isola, figlio di questo paese. (Consolo, 2012, p. 138)

Therefore, Consolo builds up his "ideale geografia letteraria siciliana", even though this is "collegata $[\ldots] a$ e in una corretta dimensione spaziale" (Consolo, 2012, p. 134), and writes the article entitled Lo spazio in letteratura in 1999. If, then, this performs a modelling function, meaning that "non si nasce in un luogo impunemente $[\ldots]$ senza essere subito segnati, nella carne, nell'anima da questo stesso luogo" (Consolo, 2012, p. 135), "La prosa dunque della narrazione nasce [...] da un contesto storico e allo stesso contesto si rivolge". This explains its character "sociale' [...] perché, in opposizione tematica e linguistica al potere, responsabile del malessere sociale $[\ldots]$ il narratore vuole rimediare almeno l'infelicità contingente". But if this civil aspect creates a risk for the hybrid genre of "il corpo letterario del racconto" (Consolo, 2012, p. 136), the narrator can also opt to

Cinzia Gallo, teaching assistant, Ph.D., Department of Humanities, Università di Catania. 
"sparire", leaving all the space "alla parte magica, alla poesia, a una comunicazione cioè anticonvenzionale, mediata". In this way, fiction "può diventare surreale, metafisico, $[\ldots]$ ricostruzione speculare, memoriale, sensoriale, struggentemente musicale, d'un mondo, un tempo irrimediabilmente perduto" (Consolo, 2012, p. 137). In both cases, Sicily is in the front line ("non so scrivere di Milano, non ho memoria..." (Consolo, 2012, p. 97).

\section{The City Conformation, Between History and Myth}

We can link the two cited aspects of the tale to the known differences that Consolo identifies between the culture of the western part and that of the eastern part of the island, in relation to which he finds himself in a position of equilibrium. ${ }^{2}$ The disappearance of this balance has devastating effects for Consolo, comparable to the action of an earthquake:

Quando un terremoto [...] squassa e polverizza città o tessuti urbani fortemente storicizzati, che nei secoli avevano cioè sviluppato una loro particolare storia, una loro cultura, una loro civiltà, oltre a distruggere vite e documenti e beni, ributta indietro i superstiti dal piano della storia al piano della natura, dell'esistenza: in pochi secondi essi fanno balzi indietro di secoli. (Consolo, 2012, p. 64)

This explains the particular significance which he attributes to Cefalù, which he defines as his "yoknapatawpha" (Consolo, 2012, p. 102) to emphasise its dual, real, and symbolic, worth. Between Cefalù and Tindari, for example, the places in which he spent his childhood are located, as celebrated in an almost mythical way in Il mare. Cefalù also appears to show him "evidenti, incontaminati, in duraturo equilibrio, gli accenti della confluenza di quel felice incontro tra la civiltà araba e la normanna” (Consolo, 2012, p. 101), which brought about the rebirth of Sicily in the past. On this subject, Consolo remembers that the Arabs set up agricultural reforms in Sicily when, upon their arrival in the year 827, they found the land in a state of total neglect. These reforms were based on a "coltivazione intensiva delle terre": "Si coltivano frutti d'ogni sorta; e la canna da zucchero, i datteri, i gelsi, ortaggi di ogni tipo; e lo zafferano, il cotone, la canapa..." (Consolo, 2012, p. 130). Tuna fishing also benefited from the arrival of the Arabs. The tuna fishers, with the "senso di liberalità, di giustizia e di tolleranza a cui era improntata quella dominazione", organised the tuna expedition on the basis of a kind of "collettivismo, di comproprietà ed egualitaria distribuzione del reddito" (Consolo, 1999, p. 40).

And it is the shape of Cefalù which expresses this dual, Arab and Norman, soul which, in La ferita dell'aprile, don Sergio regards as still being "due razze, due classi ben distinte", in which "la seconda s'impose sulla prima e si produsse questo spacco netto che dura fino ad oggi" (Consolo, 1977, p. 26). While in L'olivo e l'olivastro, the Cathedral "o fortezza o castello di Ruggiero" is "accanto e in armonia" with the "casipole con archi, altane e finestrelle del porto saraceno, del Vascio o la Giudecca" (Consolo, 1994, p. 124), in Il sorriso dell'ignoto marinaio the "case saracene sopra il porto", con "finestrelle balconi altane terrazzini tetti muriccioli bastioni archi, acuti e tondi, fori che s'aprivano impensati, a caso, con tende panni robe tovaglie moccichini

\footnotetext{
${ }^{1}$ In Uomini sotto il sole, written in 1991, which was later incorporated in Di qua dal faro, Consolo returns to these concepts: "cos'è la letteratura, la narrativa soprattutto, [...] se non politica? Politica nel senso che nasce, essa letteratura, da un contesto storico e sociale e ad esso si rivolge? E si rivolge, naturalmente, con linguaggio suo proprio, col linguaggio letterario [...]. Linguaggio che fa sì che il fatto narrato sia quello storico, sia quello politico, ma insieme sia altro oltre la significazione storica; altro nel senso della generale ed eterna condizione umana" (Consolo, 1999, p. 229).

2 As he explains: "questo paese che mi ha dato i natali ha la ventura [...] di trovarsi ai confini, alla confluenza di due regni, dove si $[\ldots]$ sfumano [...] in una sommessa risacca le onde lunghe della natura e della storia" (Consolo, 2012, p. 137).
} 
sventolanti" create a "brulicame chiassoso" in contrast with the upper part, dominated by the "gran duomo" (Consolo, 2004, p. 29). It therefore comes as no surprise that Baron Mandralisca, through whose mind the image of birds migrating towards Africa flashes, has biscuits with sesame seeds served, while his guests discuss "sul cuscus e le spezie di Tunisi e di Malta" (Consolo, 2004, p. 43). It is not mere chance that the portrait of the unknown sailor takes place in Cefalù, which means head, and in other words "ragione, mente, uomo..." (Consolo, 2004, p. 39), and more precisely in the home of Baron Mandralisca, who, reflecting, seems to be aware of the errors, of the wrongs done by men in the course of the centuries. The portrait is an expression of "razionalità", "equilibrio", "pienezza di umanità" (Consolo, 2012, p. 33), showing a picture of a man whose reason, in his adult years, has become "lama d'acciaio, [...] sempre più lucida e tagliente" (Consolo, 2004, p. 22). In the same way, the voyage undergone by the portrait of the Unknown from Messina a Cefalù, via Lipari, corresponds to the journey on which all men embark, both physically and metaphorically, "da un mare d'incertezza e rassegnato destino [...] a una terra di consapevolezza e di dialettica" (Consolo, 1999, p. 278). Cefalù is therefore the meeting point between an "oriente di natura e d'esistenza" and a "occidente di storia e di linguaggi logico-critici" (Consolo, 2004, p. 149). Once again, the spaces bear witness to this important function: Its lighthouse lights up the sea, darting "come un lampo, s'incrociava con la luna, la trapassava, lama dentro un pane tondo" (Consolo, 1977, pp. 31-32). It "sciabolava il mare" (Consolo, 2012, p. 99), sometimes along with that of Vulcano ${ }^{3}$ or Lipari. ${ }^{4}$ The towers of the cathedral appear to take on the image of minarets, thus combining the will to dominate and conquer of Ruggero II with the opening up, the invitation to engage in dialogue, the reaching out of the Arabs. The "gran rocca rotonda" of Cefalù, "sporgente sul mare" (Consolo, 2012, p. 171) therefore points to the central position of the city and Sicily in the Mediterranean, in line with the pluralist, dialectic vision of the Mediterranean which Norma Bouchard and Massimo Lollini emphasised in Reading and Writing the Mediterranean, in the views of Fernard Braudel and Franco Cassano. The Mediterranean is therefore "a space of paroxysmal interaction and dynamism" (Bouchard-Lollini, 2006, p. 15), "a geo-cultural space capable of providing many examples of the coexistence of different cultural and ethnicities and of anthropological acts of resistance to conflict, strife, and barbaric regressions" (Bouchard-Lollini, 2006, p. 18). Indeed, "nessun canale è risultato più provvidenziale, più benefico" than the Strait of Messina "per ogni passaggio da oriente a occidente, dal nord al mezzogiorno, [...] per ogni traffico, per il cammino della storia e della civiltà" (Consolo, 1999, p. 69). It is therefore spaces and places which reveal the traces of the evolution of the times, creating a kind of expressive code for Consolo.

Cefalù, "cittadina fortemente strutturata nel suo tessuto urbano, miracolosamente conservata nei fitti e significativi segni della sua storia" (Consolo, 1999, p. 278), therefore seems to be the first place to incarnate those positive values which have now vanished, unlike Palermo, even though this did constitute an "antifona" (Consolo, 2012, p. 101), or Messina. ${ }^{5}$ In La corona e le armi, then, while "Di Palermo, il ragazzino, non riusciva a capire niente, lo stordivano il caldo, il traffico, i tram, le carrozze, le automobili, [...], la gente vociante e gesticolante", in Cefalù, before the sun, "che avvampava [...] la grande rocca incombente dietro la chiesa $[\ldots]$ restò abbagliato, immobile a contemplare quello spettacolo [...]. Mai aveva visto tanta bellezza, tanta imponenza,

\footnotetext{
3 “quand'era sereno, sciabolavano lievi incrociandosi in mare" (Consolo, 2012, p. 164).

4 "vedo là in fondo, sopra il nero mare, il faro di Cefalù e quello delle Lipari, che col loro lungo raggio s'incrociavano" (Consolo, 2012, p. 235).

5 Messina is an example of "storia continuamente cancellata dalla violenza della natura", and Palermo of a "continua, atroce storia di violenza politica e sociale" (Consolo, 1999, p. 278).
} 
tanto sfolgorio" (Consolo, 2012, pp. 99-100). Palermo, which during the period of Arab domination was "una delle città più belle del Mediterraneo, una delle più prestigiose del vasto impero musulmano, un importante emporio [...]" but also "prima grande città cosmopolita dell'alto medioevo" because the Greeks, the Latins, Longobards, the Hebrews were joined by "arabi, berberi, persiani, negri” (Consolo, 1999, p. 238), has now lost its identity, in the form of its two faces, Phoenician and Saracen, and taken on the features of other large cities which have lost their personality (Milan, Bologna, Naples, Rome, Brescia, Florence) and become "città della corruzione e del massacro" (Consolo, 1994, p. 125). And there are other cities too which bear witness to the fertile interweave of cultures: Marsala, "d'antica, islamica saggezza” (Consolo, 2012, p. 71), Mazara, for Idrisi "splendida, [...] insuperabile per la posizione e il prestigio, [...]" (Consolo, 1994, p. 139), Caltagirone. In this sense, in his essay Porta Venezia, Consolo emphasises the "ondata di mediterraneità, di meridionalità", which surrounds him in this part of Milan, giving him "una sensazione di distensione, di riconciliazione" (Consolo, 2012, p. 112), and vitality, reinforced by the many families from Sicily, Calabria and Puglia who crowd the pavements of Corso Buenos Aires. It therefore comes as no surprise that, faced with the degeneration of Cefalù, in Nottetempo, casa per casa, Petro Marano decides to move to Tunis. When, from the sea, he sees its "castello bruno, le mura della Kasbah, la case bianche e azzurre, le cupole i minareti, le palme i pini le acacie, i gabbiani i fenicotteri, e i bastimenti i velieri dentro il porto" (Consolo, 1992, p. 174), it reminds him of Cefalù, confirming what La Porta defines as the "bisogno di radicarsi" (La Porta, 1995, p. 10), in other words, "una ricerca di elementi di riconoscibilità, sui quali poter appoggiare logiche di reciproca appartenenza fra luoghi e persone" (Papotti, 2014, p. 38). But at the end of the novel, perhaps the most autobiographical of the works of Consolo, in the view of Traina (2001, p. 92), Cefalù also takes on the properties of an ideal location, authorising the reference to what Bachtin calls "inversione storica" (2001, p. 294), as the positive aspects of the town, which ought to form a point of reference for the future too, have been shifted to the past. On leaving, indeed, Petro

Vide nascere man mano e lontanarsi il Castello sopra il colmo, la roccia digradante, la balza tonda, il Duomo [...], San Domenico, la caserma, Marchiafava, il Monte Frumentario, e le casipole ammassate, le mura, gli archi, le infinite finestrelle, le altane, i làstrici sul porto... Conosceva quel paese in ogni casa, muro, pietra, aveva letto ogni sua storia, ogni vicenda nei libri lasciati in eredità da don Michele, [...] l'aveva amato. [...] Ora n'era deluso, disamorato per quello ch'era avvenuto, il sopravvento, il dominio che aveva preso la peggiore gente, la più infame, l'ignoranza, la violenza, la caduta d'ogni usanza, rispetto, pietà... (Consolo, 1992, pp. 169-170)

This therefore explains how the journey of Fabrizio Clerici in Sicily, to discover "scoprire l'anticaglie e disegnar su pergamene [...] templi e colonne e statue di cittate ultrapassate" (Consolo, 2000, p. 11), emerges from the need to put down roots, caused by a sense of unease, the feeling of loss experienced by the characters in Retablo but also by contemporary man, on the basis of the dual present to which Consolo refers, and on his idea of the historic novel. ${ }^{6}$

In contact with "il mare magno di ruine" (Consolo, 2000, p. 97) of Selinunte, a city which bears witness to the positive influence of the Greeks in Sicily, Fabrizio becomes aware of the fragility of man, of the vanity and profound mystery of life, the fallacy of the presumptuous human aspirations symbolised by Milan, which are criticised by Consolo, with unconcealed allusion to the present time, by means of explicit references to v. 53

\footnotetext{
${ }^{6}$ Consolo stated in an interview, "il Manzoni scriveva del Seicento per parlare dell'Ottocento. Io ho voluto parlare del settecento per dire del nostro tempo contemporaneo" (Rustico, 2005, 2006, p. 121).
} 
("Secol superbo e sciocco") of Leopardi's Ginestra. While the cities of the past represent "il pudore, la trepidazione, il sentimento [...] la verità del mondo", those of the present express "falsità, laidezza, brutalità e follia" (Consolo, 2000, p. 104), "a la sopercheria non c'è fine, non c'è fine alla miseria [...]” (Consolo, 2000, p. 106). In the same way, while in Malophòros (Le pietre di Pantalica) the "storia di oggi", symbolised by the life as an outcast lived by Rosa, deaths at the hands of the Mafia and drugs, is a "incubo" (Consolo, 1988, p. 87), the ancient places (Selinunte, Segesta) transport us into the past, and enable us to forget the present, as Consolo repeats in Le vele apparivano a Mozia:

[...] partii alla scoperta della mia Sicilia. Che immaginavo, al di là della barriera dei Nèbrodi, [...] come una vastissima teoria di monumenti, un'unica sequenza di vestigia antiche, una distesa infinita, silente e metafisica, di pietre, di rovine. E subito s'infranse, è naturale, quella mia Arcadia contro il brulichìo, il turbinìo di vita e movimento delle contrade che traversavo. (Consolo, 2012, p. 125)

But at other times, the ancient vestiges present the interweave between "mito e storia, natura e civilizzazione, poesia e realtà, simboli e metafore, vita e morte" (Consolo, 1988, p. 115), enabling us to recover the fertile blends of cultures and civilisations which were a feature of Sicily:

[...] scivolai per il pendio che porta, oltre il fiume Selino, alla Gaggèra, dov'erano i templi più antichi, della Malophoros, di Ecate, di Zeus Meilichios. E poi, [...] arrivai alla spiaggia di sabbia dorata, al porto sepolto. E mi sembrò d'arrivare, dopo tanta calura, fatica, estraneamento per il viaggio nel remoto tempo di Selinunte, alla remissione, alla landa priva dei segni del tempo, ma che conteneva ogni tempo, compreso quello della mia memoria, di fronte all'infinito del mare, ch'era solcato di barche e, lontano, da una nave bianca, che forse andava, per quel Canale di Sicilia, verso Tunisi, Malta o Algeri. (Consolo, 2012, p. 168)

At this point, for Consolo, the statement by Giuseppe Lupo on Vittorini's Le città del mondo di Vittorini rings true: "il mito si trasfigurava in storia, il tempo immobile subiva un'accelerazione improvvisa e irreversibile, il ricordo delle civiltà scomparse si moltiplicava in scommessa futura" (Lupo, 2012, p. XXI). Indeed, it was Consolo himself who referred to Vittorini on a number of occasions. ${ }^{7}$ From the places of the past—Consolo repeats - we have to "partire per la ricostruzione, attraverso la memoria, d'una certa realtà, d'una certa storia" (Consolo, 1988, p. 118), which emphasises the importance of Sicily in the march of civilisation. In Filosofiana, in fact, don Gregorio, observing a deinos, exclaims:

Questa è una prova, ancora una prova, $[\ldots]$ che la Grecia non esiste, non è mai esistita!... La Grecia è un'invenzione degli Inglesi e dei Tedeschi, [...] Tutto si è svolto qua, in terra di Sicilia... Quale Troia, quale Micene, quale Atene, [...] Qua, qua, tutto qua è avvenuto! (Consolo, 1988, p. 67)

Along the same lines, in Lo spasimo di Palermo, and in the painting by Raphael known as Lo spasimo di Sicilia, what we see is exactly that, a spasm, a suffering that extends from Palermo from the rest of Sicily, and from there to the world.

\section{History and Memory}

Sicily therefore becomes a metaphor for the world. This is borne out by the many cultures that passed through it without ever amalgamating in full, as the island's spaces testify, in the opening pages of Uomini e paesi dello zolfo. The consequent "smarrimento del siciliano, e il suo sforzo continuo della ricerca d'identità" (Consolo,

${ }^{7}$ Cfr. 1994, pp. 14, 85; 1999, pp. 18, 97; 2012, p. 138. 
1999, p. 10) therefore correspond to the unease of contemporary man, which we've already encountered in Retablo. One response to this is the recovery of the "matrici della memoria", for which the price we have to pay is "il dovere di risalire, [...] di approdare alla terra dei padri, della società, della storia" (Consolo \& Nicolao, 1999, p. 18). In this way, we can understand how Consolo, in his Porta Venezia essay, when considering the Eritreans eating their "zichini" (Consolo, 2012, p. 114) with their hands from a communal plate, in such a way as to induce a sense of social solidarity, or the Egyptian music which seems to be "la matrice d'ogni musica mediterranea, del cante jondo andaluso, dei canti dei carrettieri siciliani, delle serenate napoletane" (Consolo, 2012, p. 115), cannot avoid remembering the melting pot of races which have passed through Sicily in the course of the centuries, and contrasting the peasant world of the south, where people ate from a communal plate, with the industrialised north, which represents "la rottura della comunione, la separazione dei corpi, la solitudine, la diffidenza, la paura d'ognuno nei confronti dell'altro" (Consolo, 2012, p. 114). In the same way, in Lo spasimo di Palermo, when Mauro's father hears young people talking on the train, he easily identifies, to his pleasure, "le città e i paesi da cui quei ragazzi provenivano. [...] Leggeva in quel concerto la storia d'ogni luogo, i segni [...] superstiti delle migrazioni, dei remoti insediamenti" (Consolo, 1998, p. 95). He therefore takes a negative view, to the point of defining it as "trucida" (Consolo, 1998, p. 94), the new language announced by Pasolini, which he sees as a kind of ratification of the denial of history.

Decay is really consequence of historical memory loss, that spaces testify. Palermo is, in fact, a city “stravolta, squallida nell'uniforme volto, nell'anonima sua morsa, nel cieco manto sopra ogni verde luce, nella grigia muraglia avanti a vecchi squarci, immobili macerie, insigni monumenti caduti o nell'inclinazione dell'imminente crollo" (Consolo, 1998, p. 79); memory is "sepolta sotto il cemento" (Consolo, 1998, p. 123). But Palermo situation is common to all world. In L'olivo e l'olivastro Consolo writes: "Via, via, lontano da quella città che ha disprezzato probità e intelligenza, memoria, eredità di storia, arte, ha ucciso i deboli e i giusti. Ma è Palermo o è Milano, Bologna, Brescia, Roma, Napoli, Firenze?" (Consolo, 1994, p. 125).

On the other hand, memory adorns reality. "Per la memoria, la poesia, l'umanità si è trasfigurata, è salita sull'Olimpo della bellezza e del valore” (Consolo, 1998, p. 53). In these words O'Connell notes a reference to Walter Benjamin'essay Angelus Novus, that Consolo mentions in Ritorni, and, in particular, to concepts of "rimembranza" and memory (O'Connell, 2008, p. 178). At this point, we can compare Consolo to Pasolini. In fact Caterina Verbaro declares, about Patmos: "La degradazione neocapitalistica del presente produce [...] per Pasolini una rimozione della memoria, [...] del passato, elementi senza i quali l'immagine della realtà risulta dimidiata e in ultima analisi 'irreale"' (2013, p. 72).

\section{Multilingualism}

Language function is bound fast to memory function. According to Consolo, in fact, "la vera scrittura è [...] quella [...] che scrive su altre scritture, la scrittura che poggia sulla memoria letteraria soprattutto" (Consolo, 2006, p. 71). In this connection, O'Connel specifies that Consolo language is "un ricco mosaico di intertestualità, le cui tessere sono fatte di testi sia antichi sia moderni" (2008, p. 164). Consolo himself explains in an interview: "sono stato appunto sperimentatore, senza però arrivare all'estensione linguistica e alla straordinaria polifonia gaddiana, ma operando verticalmente, nel senso di riportare in superficie, per necessità di estensione di significato e di significante, e innestare nel codice dato parole e strutture di lingue sepolte" (2005, p. 96). So Consolo is far from 
postmodernism, because he believes memory very important. ${ }^{8}$

The multilingualism of Lunaria and Retablo, then, which corresponds to the various "stratificazioni linguistiche" of Sicily, as well as being a means for "una ribellione alle norme" (Sinibaldi, 1988, p. 12), also serves as a mechanism for recovering our identity, which is also a way of bringing about an expressive renewal. Consolo therefore cannot help but praise the "antiche migrazioni", the "incroci fruttuosi di culture" (Consolo, 2012, p. 191) of Sicily, which manifest themselves in the language. Indeed, he attributes great importance to this:

E' pur vero [...] come ci ha chiarito Foucault, che il linguaggio identifica, ordina e classifica l'esistente, il quale da questo momento è in quanto è detto. Ma la parola ha il potere anche, qualche volta, di rendere esistente l'inesistente, di creare: [...]. (Consolo, 2012, p. 66)

"Chi vi parla [...] crede nel valore del linguaggio. [...]" (Consolo, 2012, p. 148). We can remember, for example, Arabian origin of the word "marabutto", that seals the sense of Lo spasimo di Palermo.

\section{Conclusion}

The history of Sicily therefore demonstrates how otherness is not a threat, but enrichment, and how the identity is to be found in plurality, in spite of the fact that ultimately the Mediterranean has undoubtedly been "devastato" (Consolo, 1998, p. 105). And to repeat once again how Sicily is a metaphor for the world, he states that he is "da una svariata commistione nato per caso bianco", "frutto dell'estenuazione bizantina, del dissolvimento ebraico, della ritrazione araba, del seppellimento etiope" (Consolo, 2012, p. 113). Quite rightly, then, one of the women who arrived in Cefalù in the wake of the Mormons in Nottetempo, casa per casa, declares that she is "Du monde entier" (Consolo, 1992, p. 23), thus echoing Robert who, in Le pietre di Pantalica, exclaimed, "Oh... Vive le monde tout entier!" (Consolo, 1988, p. 24).

We can, then, only conclude with the words of Franco Cassano:

Fino a quando continueremo a ritenere che lo scorrere inevitabile verso Occidente sia l'unico moto possibile del giorno e che il Mediterraneo sia solo un mare del passato, avremo puntato gli occhi nella direzione sbagliata e il degrado che ci circonda non cesserà mai di esistere. (Cassano, 2005, p. 47)

\section{References}

Bachtin, M. (2001). Estetica e romanzo. Un contributo fondamentale alla "scienza della letteratura" (Aesthetics and the novel. A fundamental contribution to the "Science of Literature"). Torino: Einaudi.

Bouchard, N. (2005). Consolo and the postmodern wrinting of melancholy. Italica, 82(1), 1-23.

Bouchard, N., \& Lollini, M. (Eds.). (2006). Reading and writing the Mediterranean. Toronto: University of Toronto Press Incorporated.

Cassano, F. (2005). Il pensiero meridiano (Southern Tought). Bari: Laterza.

Ciccarelli, A. (Ed). (2005). Intervista a Vincenzo Consolo (Interview to Vincenzo Consolo). Italica, 82(1), 92-97.

Consolo, V. (1977). La ferita dell'aprile (The pain of the April). Torino: Einaudi.

Consolo, V. (1988). Le pietre di Pantalica (The Pantalica Stones).Milano: Mondadori.

Consolo, V. (1992). Nottetempo, casa per casa (Nightly, house by house). Milano: Mondadori.

Consolo, V. (1994). L'Olivo e l'olivastro (Olive and wild olive). Milano: Mondadori.

Consolo, V. (1994). Lunaria. Torino: Einaudi.

\footnotetext{
8 "It is important to point out that even though Consolo's novels exhibit many of the rhetorical devices that we have come to associate with posmodern wrinting practices, they also remanin fundamentally distinct from dominant, majoritarian forms of postmodernism" (Bouchard, 2005, pp. 10-11).
} 
Consolo, V. (1998). Lo Spasimo di Palermo (The spasm of Palermo). Milano: Mondadori.

Consolo, V. (1999). Di qua dal faro (Here from the lighthouse). Milano: Mondadori.

Consolo, V. (2000). Retablo. Milano: Mondadori.

Consolo, V. (2004). Il sorriso dell'ignoto marinaio (The smile of the unknown mariner). Milano: Mondadori.

Consolo, V. (2006). Ma la luna, la luna... (But the moon, the moon...). In R. Pintor (Ed.), «Lunaria» vent'anni dopo («Lunaria» Twenty years later). València: Generalitat Valenciana, Conselleria de Cultura, Educació i Esport.

Consolo, V. (2012). La mia isola è Las Vegas (My island is Las Vegas). Milano: Mondadori.

Consolo, V., \& Nicolao, M. (1999). Il viaggio di Odisseo (The Odysseus' journey). Milano: RCS.

La Porta, F. (1995). La nuova narrativa italiana. Travestimenti di fine secolo (The recent Italian narrative. Mutations of fin de siecle). Torino: Bollati Boringhieri.

Lupo, G. (2012). Il viaggio cittadino di Elio Vittorini (The city travel of Elio Vittorini). In E.Vittorini. Le città del mondo (The World's Cities). Milano: BUR.

O'Connell, D. (2008). Consolo narratore e scrittore palincestuoso (Consolo Novelist and Writer of Palimpsests). Quaderns d'Italià, 13, 161-184.

Papotti, D. (2014). Racconti di città: strategie di interpretazione urbana nella collana "Contromano" (City TALES: Strategies of City interpretation in the publishing series "Contromano"). In La geografia del racconto. Sguardi interdisciplinari sul paesaggio urbano nella narrativa italiana contemporanea (The story geography: Inter-disciplinary looks on the city landscape in the contemporary Italian narrative). Bruxelles: P.I.E. Peter Lang.

Rustico, L. (2005/2006). Il paesaggio siciliano in Vincenzo Consolo: Retablo (The Sicilian landscape in Vincenzo Consolo: Retablo). Tesi di laurea, Milano: Università di Milano Bicocca.

Sinibaldi, M. (Ed.). (1988). La lingua ritrovata: Vincenzo Consolo (The recovered language: Vincenzo Consolo). Leggere, 2.

Traina, G. (2001). Vincenzo Consolo. Fiesole: Edizioni Cadmo. 